\title{
Inhibition of MMP-13 with Modified Polymer
}

\section{Particles}

\author{
Hai Tran, ${ }^{1,+}$ Kaitlin M. Bratlie, ${ }^{1,2,3, *}$ \\ ${ }^{1}$ Department of Chemical \& Biological Engineering, Iowa State University, Ames, Iowa 50011 \\ ${ }^{2}$ Department of Materials Science \& Engineering, Iowa State University, Ames, Iowa 50011 \\ ${ }^{3}$ Ames National Laboratory, Ames, Iowa 50011
}

Part of the special issue "Gabor A. Somorjai Festschrift"

CORRESPONDING AUTHOR FOOTNOTE

*To whom correspondence should be addressed: Tel: 515-294-7304, Fax: 515-294-5444, E-mail:

kbratlie@iastate.edu

${ }^{+}$Current address: Department of Chemical and Biomolecular Engineering, Cornell University, Ithaca, NY 14850

(C) 2015. This manuscript version is made available under the Elsevier user license http://www.elsevier.com/open-access/userlicense/1.0/ 


\begin{abstract}
Matrix metalloproteinases (MMPs) are proteases that destroy the extracellular matrix and have important roles in the foreign body response, wound healing, and in disease. Of particular importance is the chronic wound environment in which MMP activity is increased, resulting in destruction of the de novo extracellular matrix. One potential treatment of these wounds would be to use dressings that are capable of inhibiting MMP activity. In this study, we examined the effect of seven polymer modifiers (2-amino-3-guanidinopropionic acid, arginine, carnitine, citrulline, creatine, 3-guanidino propionic acid, and $N_{w}$-nitro-L-arginine) on MMP-13 activity. MMP-13 is a collagenase that is present in chronic wounds and is zinc dependent. Our results showed that these polymer modifiers were able to inhibit MMP-13 activity to varying degrees. The mechanism of inhibition appears to be binding zinc to the modifiers.
\end{abstract}




\section{Introduction}

Matrix metalloproteinases (MMPs) are a family of zinc-dependent proteases that are capable of cleaving the extracellular matrix (ECM) and play pivotal roles in the foreign body response,[1] fibrosis,[2] chronic wound healing,[3] and cancer.[4,5] The sequence of local events following implantation is generally regarded as the tissue response continuum in which each individual event leads to the subsequent: injury progresses to acute inflammation, which proceeds to chronic inflammation, followed by granulation tissue formation, foreign body reaction and fibrous encapsulation.[6,7] This process is facilitated by MMPs, which enable cell migration through degradation of the ECM.[8,9] In addition, MMPs can affect cell behavior by cleaving molecules attached to the cell surface, those in circulation, and pericellular molecules.[7] They are known to be involved in the cleavage of cell surface receptors, the release of apoptotic ligands, and chemokine/cytokine activation and inactivation.[10] MMPs are also thought to play a major role on cell behaviors such as cell proliferation, migration (adhesion/dispersion), differentiation,[10] angiogenesis,[11-13] apoptosis,[12,14,15] and host defense.[1,8,16,17] MMPs are produced by macrophages[4,18,19] and fibroblasts.[4,20] MMP13 is a protease against ECM components, particularly fibril collagens and gelatins. MMPs are upregulated in wound tissue. MMP-13 is expressed in granulation tissue and in chronic ulcers, but not in normal healing wounds.[21]

Arginine is metabolized in cells through inducible nitric oxide synthase (iNOS) to NO and citrulline or through arginase to ornithine and urea.[22,23] Ornithine is used to produce polyamines, which are used for cell proliferation and tissue repair. In addition to arginine conversion to polyamines through arginase and other enzymes, high expression of NO decreases collagen expression in wounds. Inhibiting NO generation abates this effect.[24] NO production 
from iNOS has been found to be coincident with MMP activity.[25] NO regulates MMP-13 release by nitrating MMP-13, thus promoting its release from endothelial cells.[26] The balance between ECM destruction through MMPs and tissue remodeling is controlled through tissue inhibitors of metalloproteases (TIMPs), typically in a 1:1 ratio.[27] This balance is disrupted in chronic wounds, allowing for increased ECM destruction.[28] Applying TIMPs to diabetic wounds in rats resulted in faster healing times compared to controls.[29] In addition to biologicals, biomaterial substrates can inhibit protease activity. Calcium binding hydrogels have been shown to inhibit trypsin, which is a Ca-dependent enzyme.[30] Hexadentate ligands have also been attached to hydrogels to inhibit Ca- and Zn-dependent enzymes.[31]

In this study, we have examined the effect of polymer modifiers on the enzyme efficiency of MMP-13. Since arginine and its derivatives are found in wounds, seven arginine derivatives were chosen to test their ability to inhibit MMP-13. A potential mechanism of zinc chelation by the modifiers is explored. These modifiers were covalently coupled to two different polymers, illustrating the ability of the modifiers to inhibit the enzymatic activity of MMP-13 similarly for both microparticles. These modifiers may have therapeutic potential in inhibiting MMP-13 activity in chronic wounds.

\section{Materials and Methods}

A total of seven modifiers were coupled to amidine polystyrene microspheres $(1.0 \mu \mathrm{m}$ diameter, Life Technologies) or to poly-L-arginine (PLR), which was coupled to poly(Nisopropylacrylamide-co-acrylic acid) (pNIPAm) particles to assess how they affect MMP-13 activity. All experiments had at least three replicates and error bars indicate the standard deviation. All materials were purchased from Sigma and used as received, unless otherwise 
indicated. Fresh deionized water (Milli-Q, Thermo Scientific Nanopure) was used throughout the study.

Surface modifiers (Figure 1) that were coupled to the microspheres were 2-amino-3guanidinopropionic acid, arginine, carnitine, citrulline, creatine (Fisher Scientific), 3-guanidino propionic acid, and $N_{w}$-nitro-L-arginine.

Modification of polystyrene particles. Amidine polystyrene microparticles $(0.2 \mathrm{~mL}$ of $5 \% \mathrm{w} / \mathrm{v})$, $20 \mathrm{mg}$ of 1-ethyl-3(3-(dimethylaminopropyl) carbodiimide hydrochloride (EDC), and $2 \mathrm{mg}$ of surface modifier (Figure 1) were added to $1 \mathrm{~mL}$ phosphate buffered saline (PBS, diluted from 10x solution, Fisher Scientific, to 0.1 M, pH 7.4) and were vortexed and incubated for $2 \mathrm{~h}$ at room temperature. The particles were centrifuged at $3000 \mathrm{~g}$ for 15 minutes five times. The particles were resuspended in deionized water.

Modification of pNIPAm particles. In a $250 \mathrm{~mL}$ round bottom flask, NIPAm (2.4 g), N,Nmethylenebis(acrylamide) (0.16 g) (BIS), and $157 \mu \mathrm{L}$ acrylic acid (AAc, J.T. Baker) were dissolved in $100 \mathrm{~mL}$ water and stirred under nitrogen for 30 minutes at $70^{\circ} \mathrm{C}$, well above the lower critical solution temperature for pNIPAm. Potassium persulfate $(200 \mathrm{mg})$ was dissolved in $10 \mathrm{~mL}$ water and added to the flask via syringe. After $4 \mathrm{~h}$, the suspension was slowly cooled to room temperature, filtered with P5 grade filter paper, dialyzed for $48 \mathrm{~h}$ against water, and freezedried using a lyophilizer (Labconco, 4.5L). The particles were determined to be $\sim 600 \mathrm{~nm}$ using SEM in a previous study.[32] Seven different molecules (Figure 1) were used to modify PLR. In a glass scintillation vial, $2 \mathrm{~mL}$ of a $2.5 \mathrm{mg} / \mathrm{mL}$ solution of PLR in phosphate buffered saline (PBS) were added to six molar equivalents of the modifiers in Figure 1. EDC (20 mg) was added to the vial and the reaction was stirred for $4 \mathrm{~h}$ at room temperature. The polymers were dialyzed against water and lyophilized. To modify the pNIPAm particles, $2 \mathrm{mg}$ of the modified PLR, 20 
$\mathrm{mg}$ EDC, and $0.2 \mathrm{~mL}$ of $5 \% \mathrm{w} / \mathrm{v}$ pNIPAm particles were suspended in $2 \mathrm{~mL}$ of PBS. These particles were reacted for $4 \mathrm{~h}$ at room temperature, dialyzed against water, and lyophilized. Zeta potential. Mili-Q water was neutralized to $\mathrm{pH} 7$ with $\mathrm{HCl}$ or $\mathrm{NaOH}$ to ensure the ions would not interfere with the measurements. The low salt concentration was confirmed by measuring conductivities $<0.05 \mathrm{mS} / \mathrm{cm}$. The zeta potential was measured with a Zetasizer Nano Z (Malvern).

Enzyme kinetic assay. MMP-13 (R\&D Systems) was diluted to $10 \mathrm{ng} / \mu \mathrm{L}$ in TNCB assay buffer (50 mM Tris, $10 \mathrm{mM} \mathrm{CaCl}_{2}, 150 \mathrm{mM} \mathrm{NaCl}, 0.05$ vol-\% Brij; $\mathrm{pH} 7.5$ ). $17 \mu \mathrm{L}$ of $10 \mathrm{ng} / \mu \mathrm{L} \mathrm{MMP}-$ 13 stock solution was added to $34 \mu \mathrm{L}$ of $0.625 \mathrm{wt}-\%$ functionalized polystyrene or pNIPAm particles. A total volume of $85 \mu \mathrm{L}$ was reached by adding $34 \mu \mathrm{L}$ of TNCB assay buffer. The samples were incubated overnight to allow the enzyme to adsorb to the particle. The following day $4.25 \mu \mathrm{L}$ of $20 \mathrm{mM}$ 4-aminophenyl mercuric acetate (APMA) was added to each tube to achieve a final concentration of $1 \mathrm{mM}$ APMA to activate the pro-form of the enzyme. The samples were incubated at $37^{\circ} \mathrm{C}$ for $2 \mathrm{~h}$. A stock solution of $6.2 \mathrm{mM}$ fluorogenic peptide substrate (Mca-KPLGL-Dpa-AR-NH 2 , R\&D Systems) in dimethylsulfoxide was diluted to $25 \mu \mathrm{M}$ substrate in TNCB assay buffer. The solution containing enzyme and functionalized particles was diluted 10-fold to achieve a final concentration of $0.2 \mathrm{ng} / \mu \mathrm{L}$ MMP-13 and was added to a black 96-well plate. The $25 \mu \mathrm{M}$ peptide substrate was added in appropriate volumes so that the final volume per well was $130 \mu \mathrm{L}$ and the final peptide concentration varied from $6-14 \mu \mathrm{M}$ to obtain Michaelis-Menten kinetic parameters. Fluorescent signals were measured with a plate reader (BioTek Synergy HT Multidetection Microplate Reader) at an excitation/emission of $320 / 400 \mathrm{~nm}$ for at least $4 \mathrm{~h}$. The plate was shaken for $10 \mathrm{~s}$ between each reading. 
Zinc binding assay. Twofold serial dilutions were made from $500 \mathrm{nM} \mathrm{ZnCl}_{2}$ to prepare a standard curve. $100 \mu \mathrm{L}$ of $500 \mathrm{nM} \mathrm{ZnCl} 2$ was mixed with $5-50 \mathrm{mM}$ of the surface modifiers. After incubating the plate for 30 minutes, $10 \mu \mathrm{L}$ of $0.1 \mathrm{mM}$ Zinquin (Enzo Life Sciences) was added to each well of the plate. The plate was incubated for 20 minutes at room temperature in the dark. Fluorescence signals were measured with a plate read are an excitation/emission of $360 / 460 \mathrm{~nm}$.

\section{Results and discussion.}

The inhibition of MMP-13 was examined using each of the substrates. Hanes-Woolf plots were constructed over a range of substrate concentrations $(6-14 \mathrm{mM})$ and the $\mathrm{K}_{\mathrm{m}}$ and $\mathrm{k}_{\text {cat }}$ were determined for each inhibitor covalently attached to amidine functionalized polystyrene particles (Table 1) and to PLR functionalized p(NIPAm-co-AAc) particles (Table 2). The fluorogenic substrate in this study - Mca-KPLG L-Dpa-AR-NH $\mathrm{NH}_{2}$ - was used as described by the manufacturer. The cleavage site for the substrate is shown in the above name between the glycine and leucine amino acids and is commonly used to study MMP kinetics.[33,34] Polystyrene particles were chosen for their similarity to tissue culture plastic, while p(NIPAmco-AAc) particles were selected for their biocompatibility and ease of chemically modifying. $[23,35,36]$ The Michaelis constant increases while the maximum rate decreases in comparison to the free enzyme, indicating mixed-type inhibition is the likely mode of inhibition. The enzyme efficiency $\left(\mathrm{k}_{\mathrm{cat}} / \mathrm{K}_{\mathrm{M}}\right)$ values decreased nine- to sixteenfold for the particles modified with the inhibitors. Inhibition on the amidine functionalized polystyrene particles was more effective as the on the PLR modified p(NIPAm-co-AAc) particles, likely due to the increased charge of the polystyrene particles.[37,38] The zeta potential of both the polystyrene and 
$\mathrm{p}(\mathrm{NIPAm}-\mathrm{co}-\mathrm{AAc})$ particles was measured. The $\mathrm{p}(\mathrm{NIPAm}-\mathrm{co}-\mathrm{AAc})$ particles were in the range of $16-23 \mathrm{mV}$ and the polystyrene particles were in the range of $40-45 \mathrm{mV}$.

The inhibitory functional group derivatives assayed here were based on an amidine moiety. Amidine is capable of inhibiting MMPs via two mechanisms: direct interaction resulting in a conformational change of the enzyme or through ligating with zinc-MMP is a zincdependent enzyme. As amidine exists predominantly in the protonated amidinium form and, therefore, is a poor Lewis acid, the question as to how can a cationic basic group such as amidine ligate zinc must be addressed. Aoki et al.[39] determined that the $\mathrm{pK}_{\mathrm{a}}$ of guanidine decreases from 12.4 to 5.9 when Zn-bound, suggesting facile deprotonation of guanidine in the presence of zinc. This suggests that arginine residues may have roles in the active centers of zinc(II) enzymes, such as MMPs. In addition, calculations on amidine-zinc complexes have shown decreases of $\sim 4 \mathrm{pK}_{\mathrm{a}}$ units.[40] This is particularly important since it is well established that the hydrophobic environment of enzymes can result in $\mathrm{pK}_{\mathrm{a}}$ decreases of 2-3 units.[41] Zincmediated chelation has been employed to generate coagulation protease inhibitors.[42] Additional mechanisms for amidine altering enzyme function, as mentioned at the beginning of the paragraph, include the formation of a salt-bridge with aspartic acid residues, resulting in conformational changes, as is the case in certain thrombin inhibitors. [42,43] The correlation between zinc binding and enzyme efficiency $\left(\mathrm{k}_{\mathrm{cat}} / \mathrm{K}_{\mathrm{M}}\right)$ is shown in Figure 2. Zinquin is able to complex $\mathrm{Zn}^{2+}$ and release a fluorescent signal in the blue region of the spectrum. The fluorescence of Zinquin is linear with the addition of $\mathrm{Zn}^{2+}$.[44] The relationship seen in Figure 2 suggests that the zinc binding ability of the polymer modifiers shown in Figure 1 is the primary mechanism for MMP-13 inhibition in this study. To test this theory, polystyrene microparticles 
were incubated with $500 \mathrm{nM} \mathrm{ZnCl}_{2}$ and the rate of cleavage of $14 \mu \mathrm{M}$ of the peptide by MMP-13 was measured. These results are shown in Figure 4.

The molecules studied for their ability to inhibit MMP-13 here are present in chronic wounds. Arginine is metabolized to citrulline and reactive nitrogen intermediates, or to ornithine and urea.[45] Ornithine is a precursor to polyamines, which are necessary for angiogenesis. As such, arginine can reverse hypercholesterolemia through increased angiogenesis.[46] Carnitine is used in cells that rely on fatty acid metabolism, such as muscles. Through carnitine's ability to shift metabolism from glycolytic to oxidative mechanisms, it is able to protect against endothelial damage cause by lipopolysaccharide and tumor necrosis factor. Both of these molecules are produced in oxidative environments, such as normal wound healing.[47] Carnitine was found to decrease necrosis in skin flaps, which are highly ischemic injuries,[48] owing to its ability to more efficiently regulate metabolism of oxidative sources in ischemic environments.[49] 3-guanidinopropionic acid is also capable of shifting metabolism from a glycolytic to oxidative mechanism.[50] These discussed four molecules (3-guanidinopropionic acid, arginine, carnitine, and citrulline) are the most inhibitory of MMP-13.

The molecules that resulted in a more modest inhibition of MMP-13 are $N_{w}$-nitro-Larginine, 2-amino-3-guanidinopropionic acid, and creatine. $N_{w}$-nitro-L-arginine is an antagonist of NO synthase, $[46,51,52]$ meaning that less $\mathrm{NO}$ will be produced in its presence. In an in vitro or in vivo context, this inhibition of NO may reduce the cleavage of MMP-13 from cells.[26] 2amino-3-guanidinopropionic acid is also an inhibitor of iNOS activity.[53] Creatine is produced from arginine and is used as an energy store for skeletal muscles and the brain. There is no link between creatine or creatinine, which are found in equilibrium in solution,[54] and NO or MMP activity that these authors were able to locate. 
As discussed previously, increased MMP activity results in chronic wounds. On the opposite end of the spectrum lies fibrosis. Fibrosis progression is associated with inhibition of MMPs. In the case of liver fibrosis, MMP-8 and MMP-13 are the key culprits.[55] Inhibiting these MMPs results in a decrease in matrix degradation necessary in healthy tissue remodeling. Increasing MMP activity is the primary mechanism for resolving liver fibrosis. [55]

\section{Conclusions}

This study demonstrates the ability of surface modifiers to alter the activity of MMP-13, likely through binding with zinc. These surface modifiers may have utility in wound dressings for chronic wounds that have an unbalanced MMP:TIMP ratio. Additionally, the modifiers here, which are derivatives of arginine, are able to decrease MMP-13 activity to varying degrees. These modifiers appear to not be MMP specific, but rather bind to zinc, thus decreasing the activity of the MMP.

\section{Acknowledgements}

This work was supported by the National Science Foundation under Grant No. CBET 1227867 and the Roy J. Carver Charitable Trust Grant No. 13-4265. The authors also acknowledge support from NSF ARI-R2 (CMMI-0963224) for funding the renovation of the research laboratories used for these studies. 


\section{References:}

[1] M.B. Ariganello, D.T. Simionescu, R.S. Labow, J.M. Lee, Biomaterials 32 (2011) 439.

[2] S. Hemmann, J. Graf, M. Roderfeld, E. Roeb, J. Hepatol. 46 (2007) 955.

[3] A.B. Wysocki, L. Staiano-Coico, F. Grinnell, J. Invest. Dermatol. 101 (1993) 64.

[4] K. Kessenbrock, V. Plaks, Z. Werb, Cell 141 (2010) 52.

[5] L.M. Coussens, B. Fingleton, L.M. Matrisian, Science 295 (2002) 2387.

[6] M.M.S. Shive, J.M.J. Anderson, Adv. Drug Deliv. Rev. 28 (1997) 5.

[7] J.M. Anderson, A. Rodriguez, D.T. Chang, Semin. Immunol. 20 (2008) 86.

[8] V.L. Martins, M. Caley, E. a O’Toole, Cell Tissue Res. 351 (2013) 255.

[9] M.P. Lutolf, J.L. Lauer-Fields, H.G. Schmoekel, A.T. Metters, F.E. Weber, G.B. Fields, J.A. Hubbell, Proc. Natl. Acad. Sci. U. S. A. 100 (2003) 5413.

[10] P. Van Lint, C. Libert, J. Leukoc. Biol. 82 (2007) 1375.

[11] K. Kessenbrock, V. Plaks, Z. Werb, (2010).

[12] L. Coussens, B. Fingleton, L. Matrisian, Science (80-. ). 295 (2002) 2387. 
[13] N.-B. Hao, Y.-H. Fan, Y. Cao, Z.-R. Zhang, S.-M. Yang, M.-H. Lü, Clin. Dev. Immunol. 2012 (2012) 948098.

[14] J.A. Eldred, L.M. Hodgkinson, L.J. Dawes, J.R. Reddan, D.R. Edwards, I.M. Wormstone, 53 (2012) 4085.

[15] S. Barrientos, O. Stojadinovic, M.S. Golinko, H. Brem, M. Tomic-Canic, Wound Repair Regen. 16 (2008) 585.

[16] D.T. Luttikhuizen, M.J. Van Amerongen, P.C. De Feijter, A.H. Petersen, M.C. Harmsen, M.J.A.V.L. Ã, M.J. van Amerongen, P.C. de Feijter, M.J. a van Luyn, Biomaterials 27 (2006) 5763.

[17] G.S. Ashcroft, M.-J. Jeong, J.J. Ashworth, M. Hardman, W. Jin, N. Moutsopoulos, T. Wild, N. McCartney-Francis, D. Sim, G. McGrady, X.-Y. Song, S.M. Wahl, Wound Repair Regen. 20 (2012) 38.

[18] J. Westermarck, V.M. Kähäri, FASEB J. 13 (1999) 781.

[19] G. a Finlay, L.R. O’Driscoll, K.J. Russell, E.M. D’Arcy, J.B. Masterson, M.X. Fitzgerald, C.M. O’Connor, Am. J. Respir. Crit. Care Med. 156 (1997) 240.

[20] J.T. Daniels, A.D. Cambrey, N.L.I. Occleston, Q. Garrett, R.W. Tarnuzzer, G.S. Schultz, P.T. Khaw, Invest. Ophthalmol. Vis. Sci. 44 (2003) 1104.

[21] M. Vaalamo, L. Mattila, N. Johansson, A.L. Kariniemi, M.L. Karjalainen-Lindsberg, V.M. Kähäri, U. Saarialho-Kere, J. Invest. Dermatol. 109 (1997) 96.

[22] M. Rath, I. MÃ̃/4ller, P. Kropf, E.I. Closs, M. Munder, Front. Immunol. 5 (2014) 1. 
[23] H.C. Bygd, K.D. Forsmark, K.M. Bratlie, Clin. Transl. Med. 3 (2014).

[24] J.E. Park, M.J. Abrams, P. a. Efron, A. Barbul, J. Surg. Res. 183 (2013) 487.

[25] Z. Gu, M. Kaul, B. Yan, S.J. Kridel, J. Cui, A. Strongin, J.W. Smith, R.C. Liddington, S. a Lipton, Science 297 (2002) 1186.

[26] T.R. Lizarbe, C. García-Rama, C. Tarín, M. Saura, E. Calvo, J.A. López, C. López-Otín, A.R. Folgueras, S. Lamas, C. Zaragoza, FASEB J. 22 (2008) 3207.

[27] D. Telgenhoff, B. Shroot, Cell Death Differ. 12 (2005) 695.

[28] R. Blakytny, E. Jude, Diabet. Med. 23 (2006) 594.

[29] K. Terasaki, T. Kanzaki, T. Aoki, K. Iwata, I. Saiki, J. Dermatol. 30 (2003) 165.

[30] F. Madsen, N. a Peppas, Biomaterials 20 (1999) 1701.

[31] F.Y. Su, K.J. Lin, K. Sonaje, S.P. Wey, T.C. Yen, Y.C. Ho, N. Panda, E.Y. Chuang, B. Maiti, H.W. Sung, Biomaterials 33 (2012) 2801.

[32] D. Wang, N. Phan, C. Isely, L. Bruene, K.M. Bratlie, Biomacromolecules 15 (2014) 4102.

[33] A. Biela, M. Watkinson, U.C. Meier, D. Baker, G. Giovannoni, C.R. Becer, S. Krause, Biosens. Bioelectron. 68 (2015) 660. 
[34] S. Ingvarsen, A. Porse, C. Erpicum, L. Maertens, H.J. Jurgensen, D.H. Madsen, M.C. Melander, H. Gardsvoll, G. Hoyer-Hansen, A. Noel, K. Holmbeck, L.H. Engelholm, N. Behrendt, J. Biol. Chem. 288 (2013) 10195.

[35] D. Wang, K.M. Bratlie, ACS Biomater. Sci. Eng. (2015) 150225134407009.

[36] D. Wang, N. Phan, L. Bruene, K.M. Bratlie, Biomacromolecules 15 (2014) 4102.

[37] B.D. Ratner, A.S. Hoffman, F.J. Schoen, J.E. Lemons, Biomaterials Science: An Introduction to Materials in Medicine, 2nd ed., Elsevier Academic Press, London, 2004.

[38] A. Gessner, A. Lieske, B. Paulke, R. Müller, Eur. J. Pharm. Biopharm. 54 (2002) 165.

[39] S. Aoki, K. Iwaida, N. Hanamoto, M. Shiro, E. Kimura, J. Am. Chem. Soc. 124 (2002) 5256.

[40] T.L. Nguyen, R.G. Panchal, I. a. Topol, D. Lane, T. Kenny, J.C. Burnett, A.R. Hermone, C. McGrath, S.K. Burt, R. Gussio, S. Bavari, J. Mol. Struct. THEOCHEM 821 (2007) 139.

[41] H. Vahrenkamp, Acc. Chem. Res. 32 (1999) 589.

[42] W.B. Young, P. Sprengeler, W.D. Shrader, Y. Li, R. Rai, E. Verner, T. Jenkins, P. Fatheree, A. Kolesnikov, J.W. Janc, L. Cregar, K. Elrod, B. Katz, Bioorg. Med. Chem. Lett. 16 (2006) 710.

[43] N.H. Hauel, H. Nar, H. Priepke, U. Ries, J. Stassen, W. Wienen, J. Med. Chem. 45 (2002) 1757. 
[44] P.D. Zalewski, I.J. Forbes, R.F. Seamark, R. Borlinghaus, W.H. Betts, S.F. Lincoln, a. D. Ward, Curr. Biol. 1 (1994) 153.

[45] J.E. Albina, C.D. Mills, W.L. Henry, M.D. Caldwell, J. Immunol. 144 (1990) 3877.

[46] J.J. Jang, H.K. Ho, H.H. Kwan, L.F. Fajardo, J.P. Cooke, Circulation 102 (2000) 1414.

[47] J.L. Flanagan, P. a Simmons, J. Vehige, M.D. Willcox, Q. Garrett, Nutr. Metab. (Lond). 7 (2010) 30.

[48] A.T. Tellioglu, K.A. Uras, T. Yilmaz, H. Alagozlu, I. Tekdemir, O. Karabag, Plast. Reconstr. Surg. 108 (2001) 959.

[49] Y.S. Pata, Y. Akbaş, M. Ünal, Ö. Aydin, K. Görür, C. Özcan, G. Polat, Int. J. Pediatr. Otorhinolaryngol. 67 (2003) 881.

[50] I. Oudman, J.F. Clark, L.M. Brewster, PLoS One 8 (2013).

[51] A.G.B. Kovach, C. Szabo, Z. Benyo, C. Csaki, J.J. Greenberg, M. Reivich, J. Physiol. 449 (1992) 183.

[52] S. Tewtrakul, P. Tungcharoen, T. Sudsai, C. Karalai, C. Ponglimanont, O. Yodsaoue, (2015).

[53] S.K. Grant, B.G. Green, J. Stiffey-Wilusz, P.L. Durette, S.K. Shah, J.W. Kozarich, Biochemistry 37 (1998) 4174.

[54] R.K. Cannan, a Shore, Biochem. J. 22 (1928) 920. 
[55] T. Kisseleva, D. a. Brenner, J. Gastroenterol. Hepatol. 22 (2007). 


\section{Figure Legend}

Table 1. Kinetic parameters for MMP-13 in the presence of the modified polystyrene particles at $37^{\circ} \mathrm{C}$.

Table 2. Kinetic parameters for MMP-13 in the presence of the modified pNIPAm particles at $37^{\circ} \mathrm{C}$.

Figure 1. (A) The chemical structures of all molecules used for the modification of polystyrene particles and PLR. (B) The reaction scheme between the particles, shown as a circle, and the molecules listed A.

Figure 2. Correlation between zinc binding constant and enzyme efficiency for polystyrene microparticles.

Figure 3. Correlation between zinc binding constant and enzyme efficiency for pNIPAm microparticles.

Figure 4. Correlation between zinc binding constant and \% rate increase for polystyrene microparticles in the presence of $500 \mathrm{nM} \mathrm{ZnCl}_{2}$. 
Table 1.

\begin{tabular}{llll}
\hline Particle modifier & $\mathrm{K}_{\mathrm{M}}(\mu \mathrm{M})$ & $\mathrm{k}_{\mathrm{cat}}\left(\mathrm{s}^{-1}\right)$ & Relative activity (\%) \\
\hline Creatine & $8.10 \pm 0.22$ & $0.991 \pm 0.015$ & 11 \\
2-Amino-3-guanidino propionic acid & $8.90 \pm 0.28$ & $1.03 \pm 0.017$ & 10 \\
$N_{w}$-nitro-L-arginine & $8.24 \pm 0.42$ & $0.868 \pm 0.027$ & 9 \\
Citrulline & $7.13 \pm 0.19$ & $0.650 \pm 0.010$ & 8 \\
Carnitine & $6.49 \pm 0.30$ & $0.629 \pm 0.015$ & 8 \\
Arginine & $8.76 \pm 0.51$ & $0.644 \pm 0.024$ & 6 \\
3-Guanidinopropionic acid & $9.02 \pm 0.40$ & $0.640 \pm 0.019$ & 6 \\
Unmodified particles & $11.4 \pm 0.28$ & $1.27 \pm 0.022$ & 10 \\
Free enzyme & $5.20 \pm 0.12$ & $5.90 \pm 0.06$ & 100 \\
\hline
\end{tabular}




\section{Table 2}

\begin{tabular}{llll}
\hline Particle modifier & $\mathrm{K}_{\mathrm{M}}(\mu \mathrm{M})$ & $\mathrm{k}_{\mathrm{cat}}\left(\mathrm{s}^{-1}\right)$ & Relative activity $(\%)$ \\
\hline Creatine & $7.86 \pm 0.37$ & $2.44 \pm 0.069$ & 27 \\
2-Amino-3-guanidino propionic acid & $6.21 \pm 0.16$ & $1.50 \pm 0.020$ & 21 \\
$N_{w}$-nitro-L-arginine & $11.6 \pm 0.50$ & $2.75 \pm 0.089$ & 21 \\
Citrulline & $8.42 \pm 0.30$ & $1.89 \pm 0.042$ & 20 \\
Carnitine & $13.1 \pm 0.60$ & $3.07 \pm 0.11$ & 21 \\
Arginine & $17.6 \pm 0.54$ & $2.28 \pm 0.061$ & 11 \\
3-Guanidinopropionic acid & $12.9 \pm 0.24$ & $1.26 \pm 0.018$ & 8 \\
Unmodified PLR p(NIPAm-co-AAc) & $17.9 \pm 0.68$ & $2.80 \pm 0.091$ & 14 \\
Free enzyme & $5.20 \pm 0.12$ & $5.90 \pm 0.06$ & 100 \\
\hline
\end{tabular}


A<smiles>N=C(N)NCC(N)C(=O)O</smiles><smiles>C[N+](C)(C)CC(O)CC(=O)[O-]</smiles><smiles>NC(=O)NCCC[C@H](N)C(=O)O</smiles>

2-amino-3-guanidinopropionic acid

$$
\text { arginine }
$$

carnitine

citrulline<smiles>CN(CC(=O)O)C(=N)N</smiles><smiles>N=C(N)NCCC(=O)O</smiles><smiles>N=C(NCCCC(N)C(=O)O)N[N+](=O)[O-]</smiles>

$$
\text { creatine }
$$

3-guanidino propionic acid

$$
N_{w} \text {-nitro-L-arginine }
$$

B

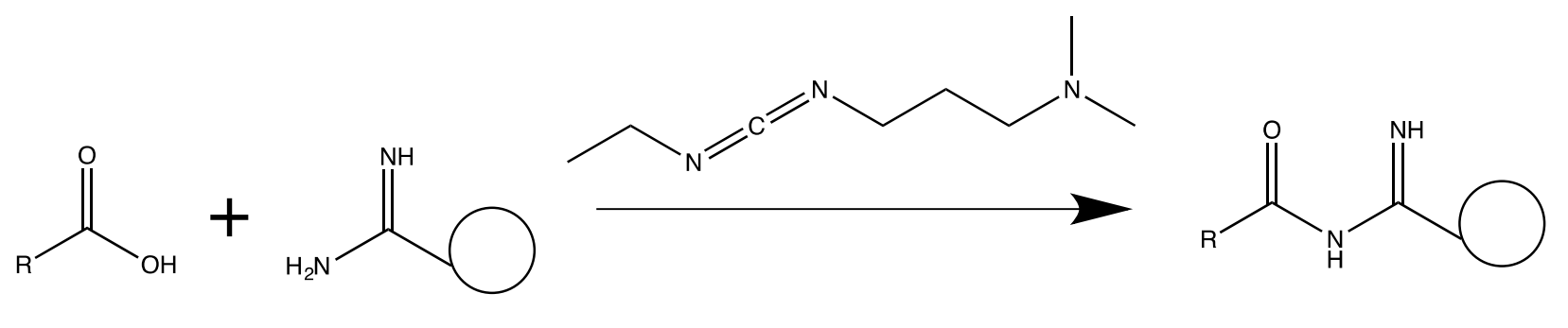

Figure 1 


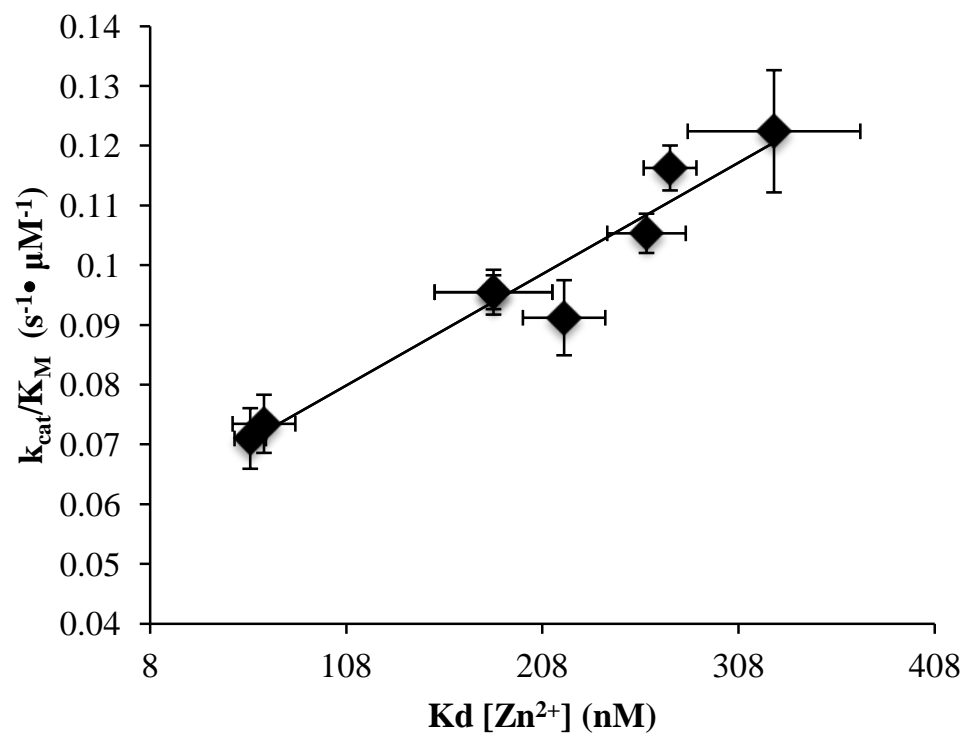

Figure 2 


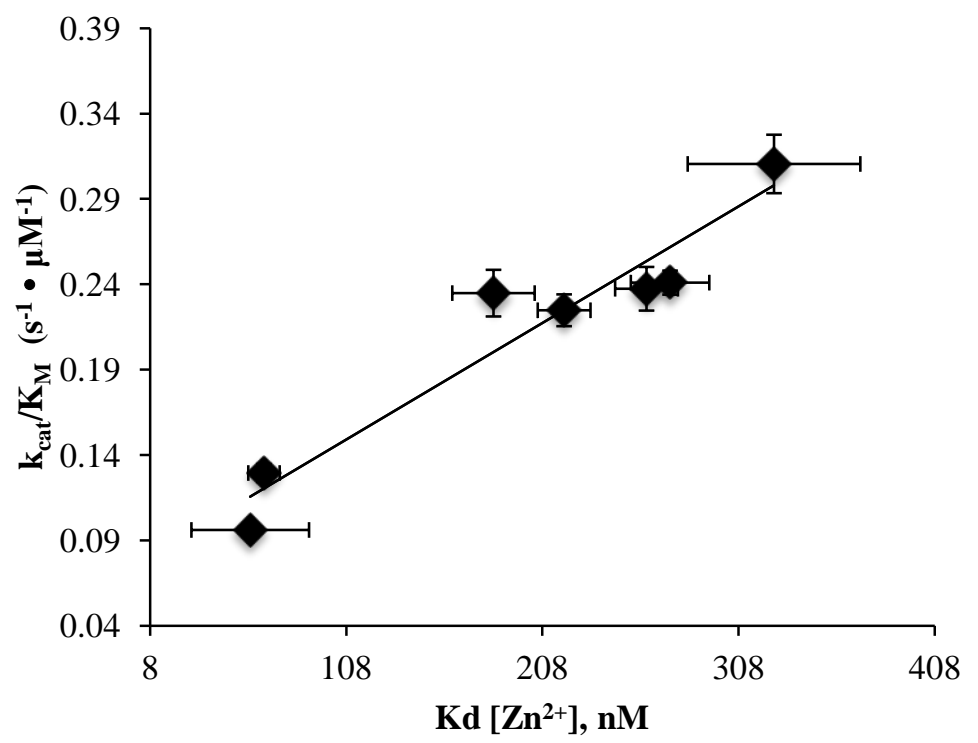

Figure 3 


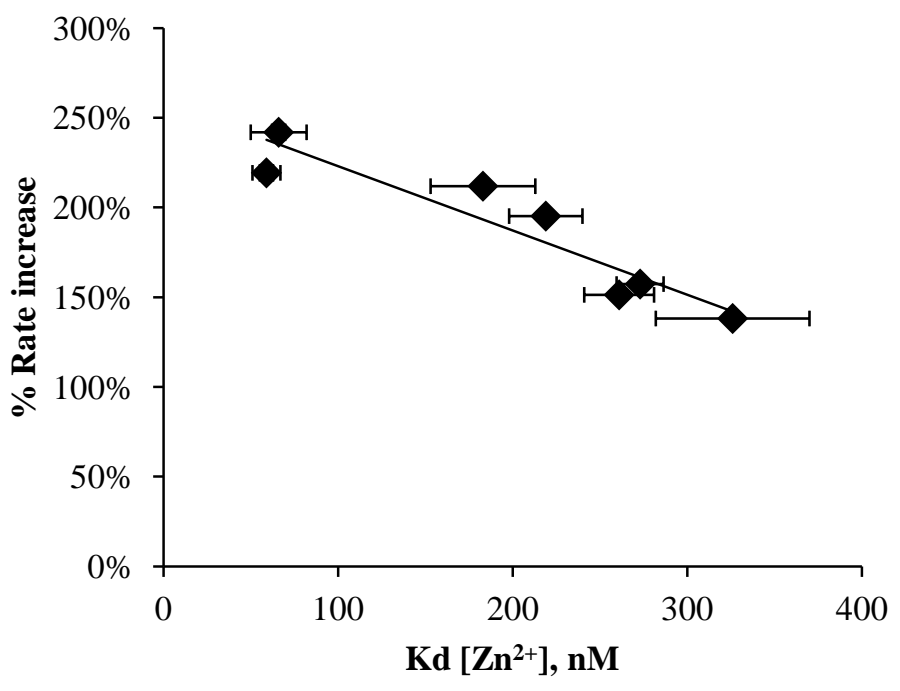

Figure 4 
Graphical Abstract

\section{Graphical Abstract}

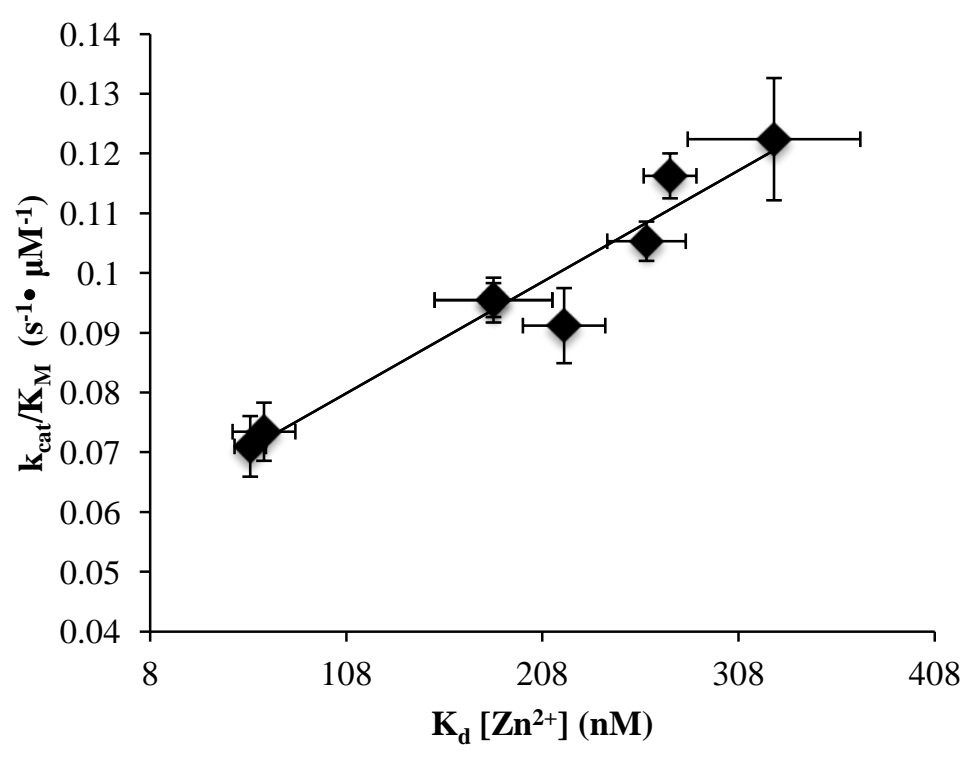

